\title{
Unexplained extensive calcification of the venae cavae extending into the right atrium causing partial obstruction of the tricuspid valve
}

\author{
Hashir Kareem, ${ }^{1}$ Tom Devasia, ${ }_{1}^{1}$ Krishnananda Nayak, ${ }^{2}$ Sumit Agarwal ${ }^{1}$
}

${ }^{1}$ Department of Cardiology, Kasturba Medical College, Manipal, Karnataka, India ${ }^{2}$ Department of Cardiovascular Technology, Kasturba Medical College, Manipal, Karnataka, India

\section{Correspondence to}

Dr Hashir Kareem, hashirkareem@gmail.com

Accepted 12 May 2014
CrossMark

\section{To cite: Kareem $\mathrm{H}$,}

Devasia T, Nayak K, et al BMJ Case Rep Published online: [please include Day Month Year] doi:10.1136/ bcr-2014-204070

\section{DESCRIPTION}

A 23-year-old woman, who had been diagnosed recently with hypothyroidism, was referred to us for an echocardiogram. She was apparently asymptomatic when she developed fatigue and mild generalised oedema. She did not have any history of chest pain, breathlessness, palpitation or syncope. Her echocardiogram revealed the following very unusual finding (figure 1, video 1). A large, irregular, highly echogenic mass was seen in the right atrium (RA), partially prolapsing through the tricuspid valve (TV) in diastole. There was mild obstruction of the TV as evidenced by increased velocity gradients across the valve. The mass seemed to be in continuity with a highly echogenic structure lining the inferior vena cava (IVC) (figure 2). Rest of the cardiac structures were normal. There was no cardiac enlargement or pericardial effusion. No evidence of pulmonary hypertension was seen. There was no history suggestive of pulmonary embolism. She underwent a CT scan which revealed extensive calcification of the IVC extending from the level of the renal veins up to the RA and also extending into the superior vena cava (SVC) (figure 3). The CT scan showed clearly that the right atrial structure was in direct continuity with the calcification in the IVC (figure 3). Moreover, the density of the structure on CTwas compatible with calcium, further proving that the structure was indeed an extension of the calcification in the IVC. In addition to this, there was a small thrombus in the RA which was not calcified. There was no evidence of

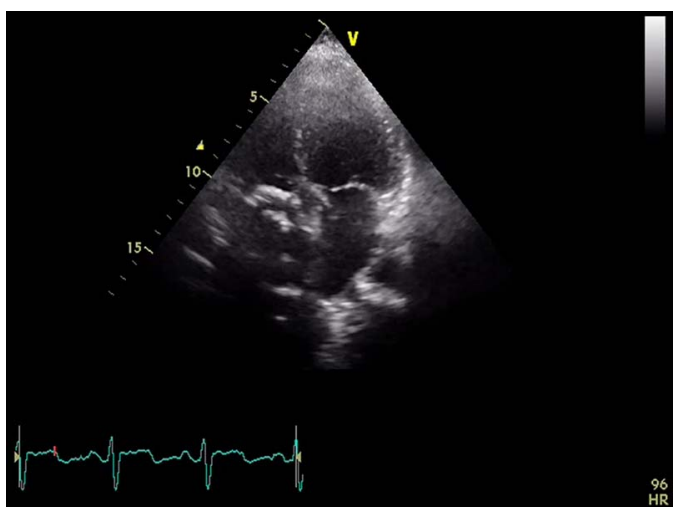

Video 14 chamber view of the echocardiogram showing the calcific structure in the right atrium prolapsing through the tricuspid valve during diastole

deep vein thrombosis of the leg. She was investigated for any evidence of thrombophilic conditions since thrombus calcification is a known cause for this type of presentation. ${ }^{1}$ Proteins $\mathrm{C}$ and $\mathrm{S}$ were normal, so were antithrombin levels. There was no evidence of antiphospholipid antibody syndrome (APLAS). Serum homocysteine was normal. Screening for connective tissue diseases was also normal. There was no evidence of parathyroid abnormality. Her serum calcium and phosphate levels were normal. Renal function was also normal.

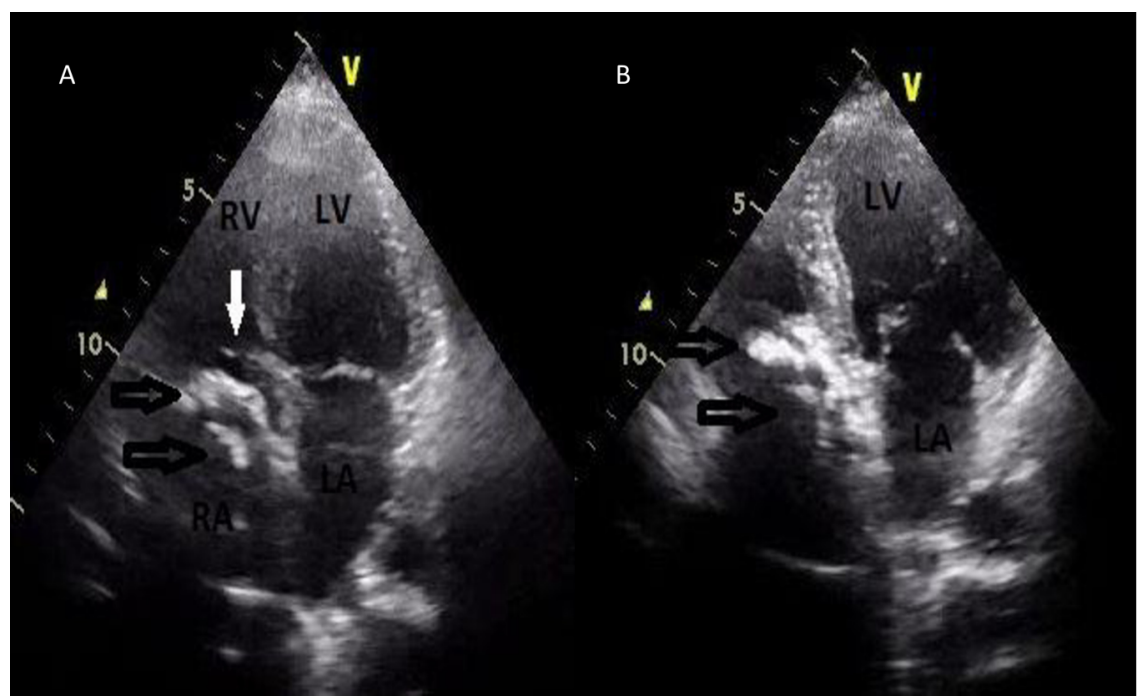

Figure 1 (A and B)Four-chamber view of echocardiogram showing the calcific structure (black arrows) in the right atrium partially prolapsing through the tricuspid valve (white arrow) into the right ventricle (RV) during diastole (B) (LV, left ventricle). 


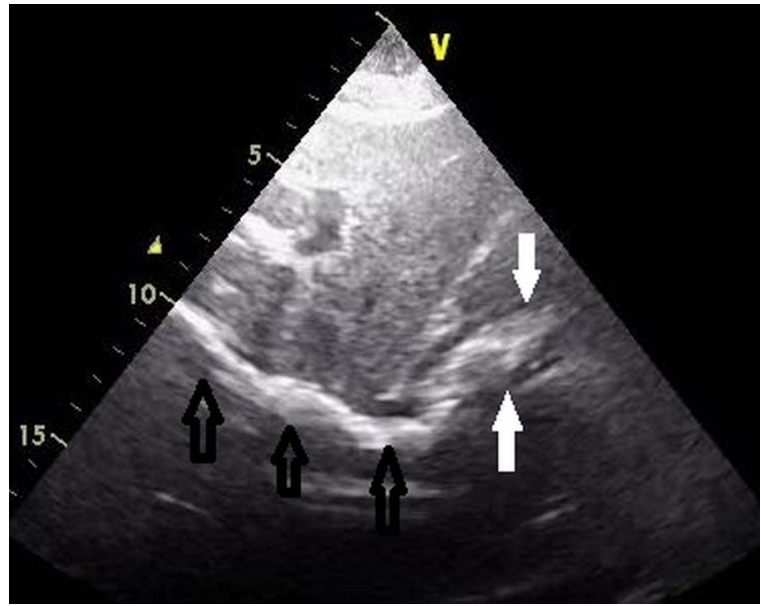

Figure 2 Subcostal view of echocardiogram showing the calcific structure in the inferior vena cava (black arrows) that is continuous with the structure in the right atrium (white arrows).

IVC calcification has been described in neonates and is associated with disseminated intravascular coagulation, placentofetal embolus, hypotensive shock, dehydration, focal infection, septicaemia and structural anomalies. ${ }^{1}$ It may also be associated with malignant disease. However, the aetiology in most cases remains unclear. ${ }^{1}$ It is extremely rare in adults and only a few cases have been reported in literature. Most patients are asymptomatic and the calcification is usually detected incidentally on X-ray or CT. Chetwood et al described a patient with IVC calcification who presented with recurrent pulmonary embolism. ${ }^{2}$ IVC calcification has been described in association with APLAS. ${ }^{3}$

The most extraordinary aspect of this case is the extension of calcification into the RA and partial prolapse of the structure through the TV. It is possible that the calcification may have extended to the RA along a pre-existing abnormal Eustachian valve. However, this is just conjecture based on the echocardiographic appearance and the exact mechanism remains a mystery. We believe that such extensive IVC calcification with extension into the RA, TV and SVC in an adult patient has not been reported before.

The patient was started on thyroid hormone supplementation and oral anticoagulation in view of the risk for pulmonary embolism. Surgical intervention was considered. However, in view of the extensive calcification, it was deemed too risky. She is currently on regular follow-up.

\section{Learning points}

- Inferior vena caval (IVC) calcification is usually found in neonates and children and is extremely rare in adults.

- IVC calcification is usually benign and detected incidentally but may occasionally be associated with pulmonary embolism.

\section{Competing interests None.}

Patient consent Obtained.

Provenance and peer review Not commissioned; externally peer reviewed.

\section{REFERENCES}

1 Silverman NR, Borns FP, Goldstein AH, et al. Thrombus calcification in the inferior vena cava. AJR Am J Roentgenol 1969;106:97-102.

2 Chetwood A, Sawiers M, Davies AJ. A calcified lesion within the inferior venacava presenting as recurrent pulmonary emboli. Vasc Surg 2011;53:204-5.

3 Cantisani V, Andreoli GM, Miglio C, et al. Diffuse inferior vena cava calcification in a patient with antiphospholipid antibody syndrome: multislice spiral CT findings \{Online\}. 29 January 2003. http://www.eurorad.org/case.php/id=2077
Figure 3 (A) CT scan-coronal section showing extensive calcification of the inferior vena cava (IVC) (black arrows) starting just above the renal veins with calcification of the superior vena cava (white arrow); (B) sagittal view showing the calcific structure extending from the IVC in to the right atrium (black arrows).

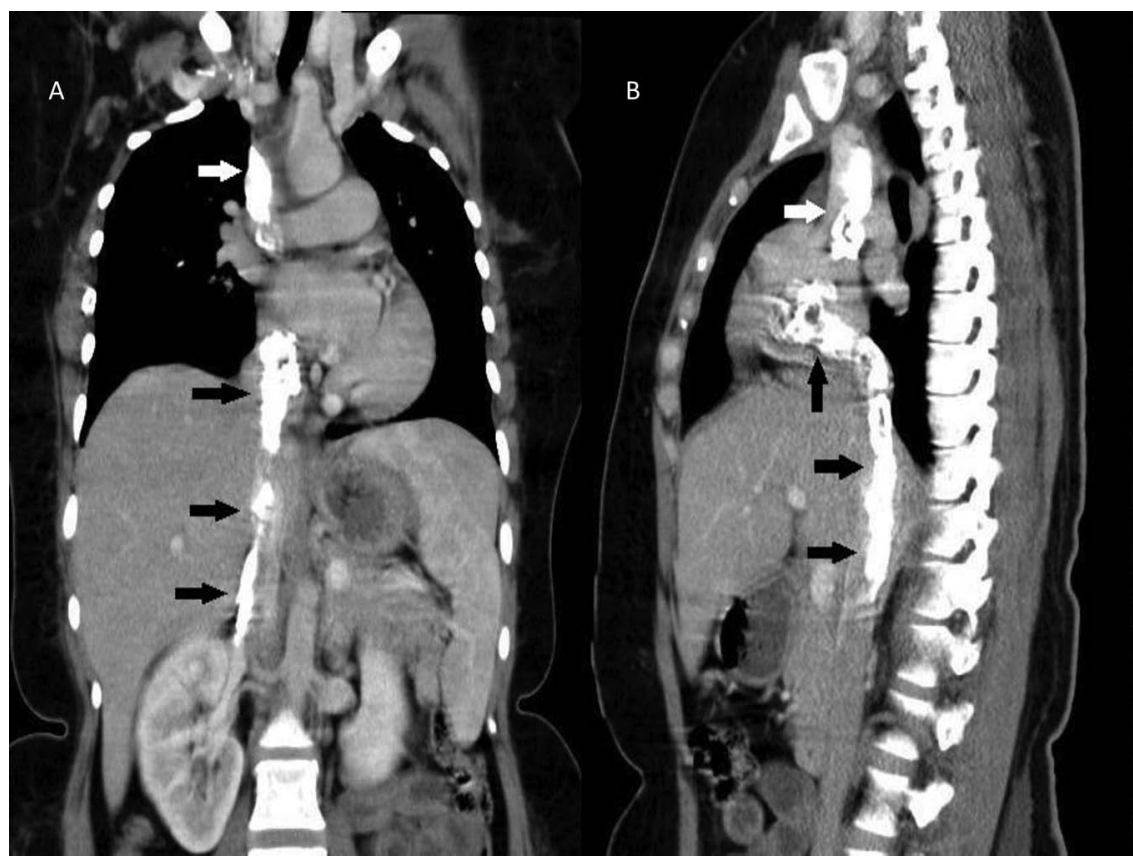


Copyright 2014 BMJ Publishing Group. All rights reserved. For permission to reuse any of this content visit http://group.bmj.com/group/rights-licensing/permissions.

BMJ Case Report Fellows may re-use this article for personal use and teaching without any further permission.

Become a Fellow of BMJ Case Reports today and you can:

- Submit as many cases as you like

- Enjoy fast sympathetic peer review and rapid publication of accepted articles

- Access all the published articles

- Re-use any of the published material for personal use and teaching without further permission

For information on Institutional Fellowships contact consortiasales@bmjgroup.com

Visit casereports.bmj.com for more articles like this and to become a Fellow 